Kabul Tarihi:05.11.2019

\title{
Tüketici Temelli Destinasyon Marka Değeri Modellemesi: Isparta Destinasyonu Örneği
}

\section{A Model of Consumer-Based Brand Equity for Destination: The Case of Isparta Destination}

\author{
Dr.Öğr. Üyesi Özgür DAVRAS \\ Süleyman Demirel Üniversitesi \\ İktisadi ve İdari Bilimler Fakültesi \\ E-posta: ozgurdavras@sdu.edu.tr
}

\section{Öz}

$\mathrm{Bu}$ araştırma tüketici temelli marka değeri boyutları (farkındalık, imaj, algılanan kalite, sadakat) arasındaki etkileşimlere dayanarak, turist davranışının temel belirleyicisi olan memnuniyet değişkeninin dahil edilmesiyle tüketici temelli destinasyon marka değerine (TTDMD) yönelik bir model önermektedir. Bu amaçla, TTDMD boyutları arasındaki etkileşimler incelenmiştir. Önerilen model Isparta ilini ziyaret eden turistler üzerinde test edilmiştir. Verilerin elde edilmesinde anket tekniğinden yararlanılmış olup, toplamda 416 anket toplanmıştır. Elde edilen veriler yapısal eşitlik modellemesi ile analiz edilmiştir. Analiz sonuçları önerilen modeli doğrulayarak, algılanan destinasyon kalitesidestinasyon memnuniyeti-destinasyon sadakati arasında güçlü ilişkinin olduğu ve diğer taraftan da destinasyon farkındalığı, destinasyon imajı ve destinasyondan algılanan kalite arasında etkileşim zincirinin olduğu da ortaya koymuştur.

Anahtar Kelimeler: Destinasyon farkındalığı, Destinasyon imajı, Algılanan kalite, Destinasyon sadakati, Destinasyon memnuniyeti

\begin{abstract}
This study proposes a model for consumer based destination brand equity (CBDBE), including the satisfaction variable, which is the main determinant of tourist behavior, based on interactions between consumer-based brand value dimensions (awareness, image, perceived quality, loyalty). For this purpose, the interactions between CBDBE dimensions were examined. The proposed model was tested on tourists visiting Isparta. The questionnaire technique was used to obtain the data and a total of 416 survey were collected. The obtained data were analyzed by structural equation modeling. The results of the analysis confirmed the proposed model and revealed that there are strong relationships among perceived destination quality, destination satisfaction and destination loyalty. On the other hand, there are chain of interactions among destination awareness, destination image and perceived quality of destination.
\end{abstract}

Key Words: Destination awareness, destination image, perceived quality, destination loyalty, destination satisfaction 


\section{Giriş}

Destinasyonlar her geçen yıl artan rekabet ortamında, kendine has çekici unsurlarıyla turist çekmek için rekabet eden ürünler olarak kabul edilmektedir (Martin, Herrero ve Salmones, 2018). Bu bağlamda rekabet avantajı sağlamanın temel stratejilerinden biri olan marka değeri yaratma, destinasyonlar için olumlu imaj oluşturma ve turist sadakati oluşturmada güçlü bir farklılaşma ve rekabetçi pazarlama strateji aracı olarak görülmektedir (Boo, Busser ve Baloğlu, 2009; Im, Kim, Elliot ve Han, 2012). Dolayısıyla bir destinasyonun marka değerinin ölçülmesi ve bilinmesi önem arz etmektedir. Marka değeri yaratma yöntemlerinden biri olan Tüketici Temelli Marka Değeri (TTMD) Aaker (1991) ve Keller (1993) tarafından önerilmiş olup, marka farkındalığı, marka imajı, algılanan kalite ve marka sadakati boyutlarından oluşmaktadır. Ürün ve hizmetlerin markalaşmasına yönelik faaliyetlerin yapılabileceğini öneren bu modelinin turizm destinasyonları üzerinde de uygulanabileceğini yapılan araştırmalar ortaya koymuştur (Boo ve diğ., 2009; Gartner ve Ruzzier, 2010; Gomez, Lopez ve Molina, 2015; Im ve diğ., 2012; Konecnik, 2006; Konecnik ve Gartner, 2007; Pike, Bianchi, Kerr ve Patti, 2010; Wong, 2015). TTDMD modeli olarak ele alan bu çalışmaların bazılarında destinasyon marka değerini oluşturan boyutlar arasındaki ilişkileri incelemeye ve geliştirmeye (Pike ve diğ., 2010; Yağmur ve Kolukısa, 2016), bazıları boyutların genel marka değeri üzerindeki etkilerini ortaya koymaya (Boo ve diğ., 2009; Im ve diğ., 2012; Kocaman ve Güngör, 2012), bazıları da farklı değişkenlerle (destinasyon deneyimi, ağızdan ağza pazarlama vb.) öncüllerini veya başka değişkenler üzerindeki etkilerini belirlemeye odaklanmıştır (Chekalina, Fuchs ve Lexhagen, 2016; Guervos, Jamilena, Pena ve Olmo, 2018; Pektaş, 2017; Yang, Liu ve Li, 2015). Sınırlı sayıdaki bazı çalışmalar (Martin ve diğ., 2018; Nam, Ekinci ve Whyatt, 2011) destinasyon memnuniyet değişkenini TTDMD modeli içine dahil etmişlerdir. Tüm bunlar göz önüne alınarak, mevcut çalışmada TTDMD boyutlarının destinasyon sadakati ve destinasyon memnuniyeti üzerinde anlamlı etkiye sahip olduğu öngörülmüştür. Bu bağlamda bir araştırma modeli önerilerek değişkenler arasındaki ilişki ampirik bir çalışma ile incelenmiştir.

Bu çalışma, TTDMD boyutlarının destinasyon memnuniyeti üzerindeki etkilerini belirleyerek, bir destinasyon marka değeri modellemesi önermektedir. Çalışma sonuçlarının alanyazına katkısı, önerilen modele destinasyon memnuniyet değişkenin de ilave edilmesidir. Memnuniyet, pazarlama faaliyetlerinin temel amacı ve genel olarak tüketicilerin refahı için son derece önemli olan davranışsal bir olgudur (Martin ve diğ., 2018). Diğer taraftan bir ürünü deneyim eden turistlerin gelecekteki davranışları, deneyim sağladıkları üründen duydukları memnuniyetten etkilenmektedir (Albayrak ve Caber, 2013). Ayrıca alanyazında memnuniyet ve sadakat arasında yapılan kapsamlı çalışmaların da (Chi ve Qu, 2008; Fuchs, Chekalina ve Lexhagen, 2012), iki değişken arasındaki güçlü ilişkilerin (memnuniyetin algılanan kalitenin sonucu ve sadakatin öncülü) olduğunu ortaya koymuş olmasından dolayı destinasyon memnuniyeti TTDMD modeline dahil edilmiştir.

Araştırmada önerilen model, Isparta ili destinasyonunu ziyaret eden turistler üzerinden elde edilen veriler doğrultusunda test edilmiştir. Deniz-kum-güneşe dayalı yaz turizmi haricinde çok sayıda ve önemli alternatif turizm potansiyeline sahip olan Isparta destinasyonunda; Davraz Kayak Merkezi ile kış turizmi, gölleri ve kanyonları ile doğa turizmi, gül ve lavanta bahçeleri ile kırsal turizm faaliyetleri ön plana çıkmaktadır (İşler, 2018: 136). Gül ve lavanta bahçelerini 2016 yılında 21 bin, 2017 yılında 140 bin, 2018 yılında yaklaşık \% 1000'lik artış ile 222 bin civarında turistin ziyaret etmesi (https://trthaber.com, 19.09.2019), Isparta ilinin kırsal turizm açısından büyük bir potansiyele sahip olduğunu göstermektedir. Dolayısıyla, bu çalışma ile elde edilecek 
Isparta destinasyonuna ait marka değeri bulguları, destinasyonun geliştirilmesine yönelik doğru stratejilerin uygulanmasında yol gösterici olacaktır.

Özet olarak bu çalışma, TTMD boyutları (destinsyon memnuniyet değişkeni de dahil) arasındaki etkileşimleri tespit ederek TTDMD yönelik farklı bir model önermektedir. Bu çerçevede öncelikle TTDMD ile teorik bilgiler verilmiş, sonrasında araştırma modelinde yer alan hipotezlerin alanyazına dayandırılarak teorik altyapıları açıklanmıştır. Çalışmanın son bölümünde yapısal eşitlik modellemesi ile önerilen model test edilmiş olup, elde edilen bulgular yorumlanarak, gelecekte yapılabilecek araştırmalara öneriler sunulmuştur.

\section{Kavramsal Çerçeve}

\subsection{Tüketici Temelli Destinasyon Marka Değeri}

Marka kavramı Amerikan Pazarlama Birliği tarafından, "bir üretici veya satıcının ürün veya hizmetlerini tanımlamaya ve rakiplerin mal veya hizmetlerinden farklılaştırmaya yönelik bir isim, terim, sembol, işaret, tasarım veya bu unsurların bir bileşimi olarak" tanımlanmaktadır (Kotler, Bowen ve Makens, 2005). Yalnız bu noktada markalar sadece isim ve sembollerden ibaret olmayıp tüketiciler ile olan ilişkilerinde, tüketicilerin bir ürün ve performansı hakkındaki algılarını ve duygularını temsil eden ana unsur olarak görülmektedir (Fuchs ve diğ., 2012). Markalar tüketicilere sunduğu işlevsel, duygusal ve kendini ifade etme gibi çok çeşitli değerler ile anıldığından dolayı, bir markanın değeri marka ve tüketici arasındaki ilişkinin fonksiyonu olarak gerçekleşmektedir (Çetin, 2017: 91). Marka değeri alanyazında, tüketici ve finans temelli yaklaşımlar olmak üzere iki farklı açıdan ele alınmıştır. Finansal açıdan marka değeri bir markanın parasal ederi/değeri olarak nitelendirilirken, tüketici temelli marka değeri, tüketici zihnindeki algısal değer olarak tanımlanmaktadır (Pektaş, 2017).

Tüketicilerin bir markaya yönelik tutum, davranış ve algı süreçlerini irdeleyen ve tüketicilerin bir markaya bağlı olma gücünün bir ölçüsü veya tüketicinin marka hakkında sahip olduğu bilgi ve inançlarının bir açıklaması olarak (Martin ve diğ., 2018) tanımlanan TTMD, marka değeri yaratmada ve marka değerini sürdürmede stratejik bir araç olarak görülmektedir (Yüce, 2010:1-2). TTMD alanyazında yoğun bir şekilde ele alınmış ve hem araştırmacılar hem de pazarlamacılar tarafından ölçme yönlü çalışmalar yapılarak, birtakım yöntem ve yaklaşımlar geliştirilmiştir. Bu çalışmaların ortak noktası, tüketici algılamaları ve tüketicinin marka ismine gösterdiği tepkinin analiz edilmesi olmuştur (Yıldız, 2015). Bu tepkileri ve algılamaları neye göre edindikleri, neye göre verdikleri ve bu algı ile tepkilerin ortaya çıkmasına neden olan faktörlerin bilinmesi TTMD araştırmalarının temelini oluşturmaktadır (Kocaman ve Güngör, 2012). TTMD oluşturulmasına yönelik temel yaklaşım Aaker (1991: 68) ve Keller'in (1993) ortaya koymuş olduğu modeller oluşturmakta olup, alanyazında çoğunlukla Aaker'in (1991) dört boyutlu modeli (marka farkındalığı, marka imajı, algılanan kalite ve marka sadakati) tercih edilmiş ve birçok araştırmada (Kim, Kim ve Jeong, 2003; Liu, Wong, Tseng ve Chang, 2017; Seric, Saura ve Molina, 2014; Yıldız, 2015) kullanılmıştır.

Ürün ve hizmet özelliklerine yönelik uygulanan Aaker'in TTMD dört boyutlu modeli, Konecnik ve Gartner (2007) tarafından destinasyon marka değeri oluşturmaya yönelik te uygulanabileceğini ortaya koyuldu ve sonraki çalışmalar (Boo ve diğ., 2009; Im ve diğ., 2012; Ruzzier, 2010; Yang ve diğ., 2015) bu modelin geçerliliğini farklı destinasyon ve örneklem gruplarında doğruladı. Bu araştırmalarda, TTMD alt boyutlarını, destinasyon farkındalığı, destinasyon imajı, destinasyondan algılanan kalite ve destinasyon sadakati olarak uyarlanmıştır. Son yıllarda yapılan bazı 
çalışmaların (Martin ve diğ., 2018; Fuchs ve diğ., 2012) destinasyon memnuniyeti değişkeni de modele dahil ettikleri görülmektedir. Turizm perspektifi açısından, bu alt boyutlara ait yazınsal bilgi aşağıda verilmiştir.

Destinasyon farkındalığı, turistin bir destinasyon bölgesini tanıması, anımsaması, ve destinasyona ait özellikleri akılda tutabilmesi olarak tanımlanmaktadır (Kim, Jin-Sun ve Kim, 2008). Başka bir ifadeyle destinasyon farkındalığı, turistin destinasyon hakkındaki bilgisini veya turistlerin zihnindeki destinasyon bilinirliğini yansıtacaktır (Martin ve diğ., 2018). Destinasyon farkındalığı, turistlerin bir destinasyon hakkında elde ettikleri bilgiler olarak tanımlanmış ve bir destinasyon ile ilgili algı oluşabilmesi öncelikle o destinasyonun farkında olunması, bilinmesi koşuluna bağlı olduğu belirtilmektedir (Pektaş, 2017: 23). Konecnik ve Gartner (2007) bir destinasyonun gelişimi için öncelikle destinasyon farkındalığının oluşturulması gerekliliğini, Boo ve diğ., (2009) ise destinasyon farkındalığının TTDMD modelinin en önemli boyutu olduğunu ve turist satın alma kararında ana etken olduğunu ortaya koymuşlardır.

Destinasyon imajı, destinasyonun gerçekliğini yansıtabilecek çeşitli özelliklere ilişkin bireysel algılardan oluşan bir dizi seti temsil etmesinin (Martin ve diğ., 2018) yanı sıra, bir turistin bir destinasyon hakkındaki sahip olduğu tüm izlenim, bilgi, önyargı ve duygusal düşüncelerinin anlatımı olarak ta tanımlanmaktadır (Kavacık, Zafer ve İnal, 2012). Başka bir ifadeyle, destinasyona ait çekici özelliklerin, destinasyonu aynen yansıtarak turistin zihninde yer almasıdır (Çetinsöz ve Karakeçili, 2018). TTDMD modelinde en önemli bileşen olarak kabul edilen destinaston imajı (Boo ve diğ., 2009; Konecnik ve Gartner, 2007), turist memnuniyeti, turistlerin tatil seçim süreci ve destinasyonu tekrar ziyaret etme niyetleri üzerinde etkili olduğunu ortaya konulmuştur (Chen ve Tsai, 2007; Chi ve Qu, 2008; Choi, Tkachenko ve Sil, 2011). Aynı zamanda destinasyon imajı destinasyonlar arası rekabette en önemli araç olup, destinasyon konumlandırma stratejilerinde en önemli amaç, destinasyona yönelik olumlu bir imaj oluşturmak veya destinasyonun sahip olduğu imajı daha da güçlendirmede önemli rol oynamaktadır (Kavacık ve diğ., 2012).

Algılanan destinasyon kalitesi, algılanan ürün değerinin bir öncülü olup (Boo ve diğ., 2009), mükemmellik veya genel üstünlüğe dayanan bütünsel bir yargı olarak tanımlanmaktadır (Martin ve diğ., 2018). Bir destinasyon için kalite, turistlerin beklentilerinin karşılanması veya aşılması olarak nitelendirilmektedir. Ancak destinasyonun birden fazla unsurlardan oluşması, başka bir ifadeyle çok sayıda iç ve dış paydaşının olması sebebiyle turistlere zamanında hizmet vermeyi zorlaştırmaktadır. Ayrıca iç paydaşların büyük bir çoğunluğunun özel işletmelerden oluşması da hizmet kalitesinin kontrol edilmesini zorlaştırmaktadır. Tüm bunlar algılanan destinasyon kalitesini etkilemektedir (Yağmur ve Kolukısa, 2016). Aaker (1996) TTMD modelinde algılanan kaliteyi modelin en önemli bileşeni olarak, Konecnik ve Gartner (2007) ise algılanan kalitenin tüketici davranışını etkileyen en önemli unsur olduğunu ileri sürmüştür.

Destinasyon memnuniyeti, turistin destinasyon deneyiminden elde ettiği bilişselduyusal bir durumdur (Martin ve diğ., 2018). Başka bir ifadeyle, destinasyonu oluşturan farklı özelliklerin performanslarının turistler tarafından genel değerlendirmesi olarak ta tanımlanabilir. Destinasyonu oluşturan özelliklerinin performansının artırılması ile yüksek destinasyon memnuniyeti sağlanması kuvvetli olasılıktır. Ayrıca araştırmalar destinasyon memnuniyetinin destinasyon sadakatinin öncülü olduğunu tespit etmiştir (Chi ve Qu, 2008; Hernandez, Radilla ve Sanchez, 2006). 
Destinasyon sadakati, TTDMD'nin temel boyutunu temsil etmekte olup, turistin bir destinasyona bağlılığı olarak tanımlanmaktadır (Yang ve diğ., 2015). Bir turistin bir destinasyona bağıılığı, gelecekte aynı destinasyonu tercih etmesinde güçlü bir belirleyici olarak görülmektedir (Wong, 2015). Destinasyon sadakati alanyazında davranışsal ve tutumsal sadakat olmak üzere iki kategoride sınıflandırılmaktadır. Davranışsal sadakat, bir turistin aynı destinasyona tekrar ziyaret etmesini kapsarken, tutumsal sadakat turistin deneyim elde ettiği bir destinasyonu ağızdan ağza pazarlama ile tavsiye etmesini ifade etmektedir (Kim ve diğ., 2008). Çetinsöz ve Artuğer (2013) TTDMD boyutları arasında destinasyon sadakatinin en önemli bileşen olduğunu ortaya koymuşlardır.

\subsection{Tüketici Temelli Destinasyon Marka Değeri Boyutları Arasındaki Etkileşimler}

Yüksek marka değerine sahip olan destinasyonların rekabet avantajı sağlamaları ve turizmden daha fazla pay alabilmeleri sebebiyle TTDMD alanyazında yoğun bir şekilde ele alınmış, TTDMD'yi oluşturan boyutlar arasındaki ilişkiler incelenmiştir. Bu boyutlardan marka farkındalığı marka sadakatinin ilk adımını oluşturmaktadır (Boo ve diğ., 2009; Konecnik, 2006). Diğer taraftan marka farkındalık seviyesi ne kadar yüksek olursa marka değerinin de o kadar yüksek olduğu kabul edilmektedir (Martin ve diğ., 2018). Keller'e (1993) göre, marka değeri marka bilgisinin kavramsallaştırılması ile oluşmakta olup, marka bilgisinin marka farkındalığı ve marka imajından oluştuğunu ileri sürmüştür. Marka farkındalığı tüketicinin markayı tanıması ve hatırlaması ile ilgiliyken, marka imajı ise marka ile ilgili bir takım özelliklerin tüketicilerin zihinde yer edinmesini ifade etmektedir. Marka farkındalığı da bu özelliklerin tüketici zihninde oluşumunu etkilemesinden dolayı, bir destinasyonun farkındalığının artması destinasyon imajını da artırması beklenmektedir (Martin ve diğ., 2018). Yapılan araştırmalar da marka farkındalığı ile marka imajı arasında olumlu yönde bir ilişkinin olduğunu ortaya koymuştur. Örneğin Kocaman ve Güngör (2012) Alanya destinasyonunun, Çetinsöz ve Artuğer (2013) Antalya destinasyonun marka değerini ölçtükleri çalışmalarında; marka farkındalığı ile marka imajı arasında pozitif yönlü ilişkiler tespit etmişlerdir. Benzer şekilde Çetinsöz ve Karakeçili (2018) Anamur destinasyonun marka değerini ele aldıkları çalışmalarında destinasyon farkındalığının destinasyon imajını olumlu yönde etkilediği sonucuna ulaşmışlardır. Tüm bu açıklamalar doğrultusunda araştırmanın ilk hipotezi aşağıdaki gibidir.

\section{H1: Destinasyon farkındalığı destinasyon imajını pozitif yönde etkiler}

Marka farkındalığı ile algılanan kalite arasında ilişkinin olduğuna dair çalışmalar da alanyazında mevcuttur. Örneğin Aktepe ve Baş (2008) çalışmalarında marka sadakati ile marka farkındalığı arasında doğrusal bir ilişkinin olduğunu tespit etmişlerdir. Kim ve Kim (2005) lüks otel ve zincir restoran işletmeleri üzerinde yaptıkları çalışmalarında tüm marka değeri bileşenlerinin önemli bulmalarında rağmen, marka farkındalığı ve algılanan kalitenin işletmelerin performansını olumlu yönde daha fazla etkilediğini ortaya koymuşlardır. Çetinsöz ve Artuğer (2013) destinasyon farkındalığı ile algılanan destinasyon kalitesi arasında pozitif yönlü ilişkiler tespit etmiş olup, Çetinsöz ve Karakeçili (2018) de destinasyon farkındalığının algılanan destinasyon kalitesini etkilediğini ortaya koymuşlardır. Bu bulgular doğrultusunda araştırmanın ikinci hipotezi oluşturulmuştur: etkiler.

H2: Destinasyon farkındalığı algılanan destinasyon kalitesini pozitif yönde 
Üçüncü olarak, tüketici davranışı ile ilgili yapılan araştırmalar algılanan kalitenin marka imajından etkilendiğini ortaya koymuştur. Hankinson (2005) destinasyon imajı ile algılanan kalite arasında pozitif yönlü ilişkiler olduğunu ortaya koymuş olup, Chen ve Tsai (2007) Tayvan'ın Kengtin turizm merkezinde, Çetinsöz ve Karakeçili (2018) Anamur destinasyonunda yapmış oldukları çalışmalarında, destinasyon imajının algılanan destinasyon kalitesini olumlu yönde etkilediğini belirlemişlerdir. Benzer şekilde Cretu ve Brodie (2007) çalışmalarında marka imajının algılanan kaliteyi etkilediği sonucuna ulaşmışlardır. Dolayısıyla, destinasyon imajının bir turistin destinasyonla ilgili çekici unsurlara yönelik algılarına yönelik oluştuğu göz önüne alındığında, destinasyon imajının algılanan destinasyon kalitesini artıracağı söylenebilir (Martin ve diğ., 2018). Tüm bu bulgular ve teze dayanarak üçüncü hipotez aşağıdaki gibi oluşturulmuştur.

H3: Destinasyon imajı algılanan destinasyon kalitesini pozitif yönde etkiler.

Tüketici davranışı konusunda alanyazında yapılan araştırmalar, genelde algılanan kalitenin memnuniyetin ve sadakatin belirleyicisi olduğunu ortaya koyduğundan (Chen ve Chen, 2010; Gonzalez, Comesana ve Brea, 2007; Zabkar, Brencic ve Dmitrovic, 2010), algılanan kalite ile memnuniyet ve sadakat arasında pozitif yönde bir ilişki olduğu söylenebilir. Çetinsöz ve Artuğer (2013) de bu ilişkiyi doğrular sonuçlar elde etmişlerdir. Callarisa, Garcia, Cardiff ve Roshchina (2012) ile Hsu, Oh ve Assaf (2012) algılanan marka kalitesinin marka sadakati üzerinde etkili olduğunu ortaya koymuşlardır. TTDMD araştırmalarında algılanan kalitenin destinasyon memnuniyeti ve sadakati üzerindeki etkileri de tespit edilmiştir. Örneğin Chen ve Tsai (2007) ile Martin ve diğ. (2018) algılanan kalitenin destinasyon memnuniyetini; Boo ve diğ. (2009) ile Yang ve diğ. (2015) algılanan kalitenin destinasyon sadakatini olumlu yönde etkilediğini tespit etmişlerdir. Koçoğlu (2019) da destinasyon imajı ile destinasyon sadakati arasındaki ilişkide algılanan destinasyon kalitesinin kısmi aracılık rolü olduğunu tespit etmiştir. Tüm bulgular doğrultusunda dördüncü ve beşinci hipotezler aşağıdaki şekilde oluşturulmuştur:

H4: Destinasyondan algılanan kalite destinasyon memnuniyetini pozitif yönde etkiler. etkiler.

H5: Destinasyondan algılanan kalite destinasyon sadakatine pozitif yönde

Son olarak memnuniyet, bir bireyin tüketim deneyiminden sonra o ürüne yönelik sadakat oluşumunda önemli rol oynayan davranışsal bir değişken olarak kabul edilmektedir (Martin ve diğ., 2018). Marka sadakati, tüketicinin aynı markayı tekrar satın alma niyeti ve markayı başkalarına tavsiye etme isteğinden oluşmaktadır. Turizm alanında yapılan çalışmalar, bir destinasyonu tekrar ziyaret etme niyetinin ve destinasyonu başkalarına tavsiye etme isteğinin turist memnuniyetinden etkilendiğini ortaya koymuştur. Fuchs ve diğ. (2012) İsveç'te, Chi ve Qu (2008) Amerika'da yaptıkları çalışmalarında destinasyon memnuniyetinin destinasyon sadakatini olumlu yönde etkilediğini ortaya koydu. Nam ve diğ. (2011) ise destinasyon memnuniyetinin destinasyon sadakatine aracılık etkisi olduğu sonucuna ulaşmışlardır. Bu bulgulara göre, araştırmanın son hipotezi belirlenmiştir.

H6: Destinasyon memnuniyeti destinasyon sadakatini pozitif yönde etkiler 


\section{Şekil 1: Araştırmanın Modeli}

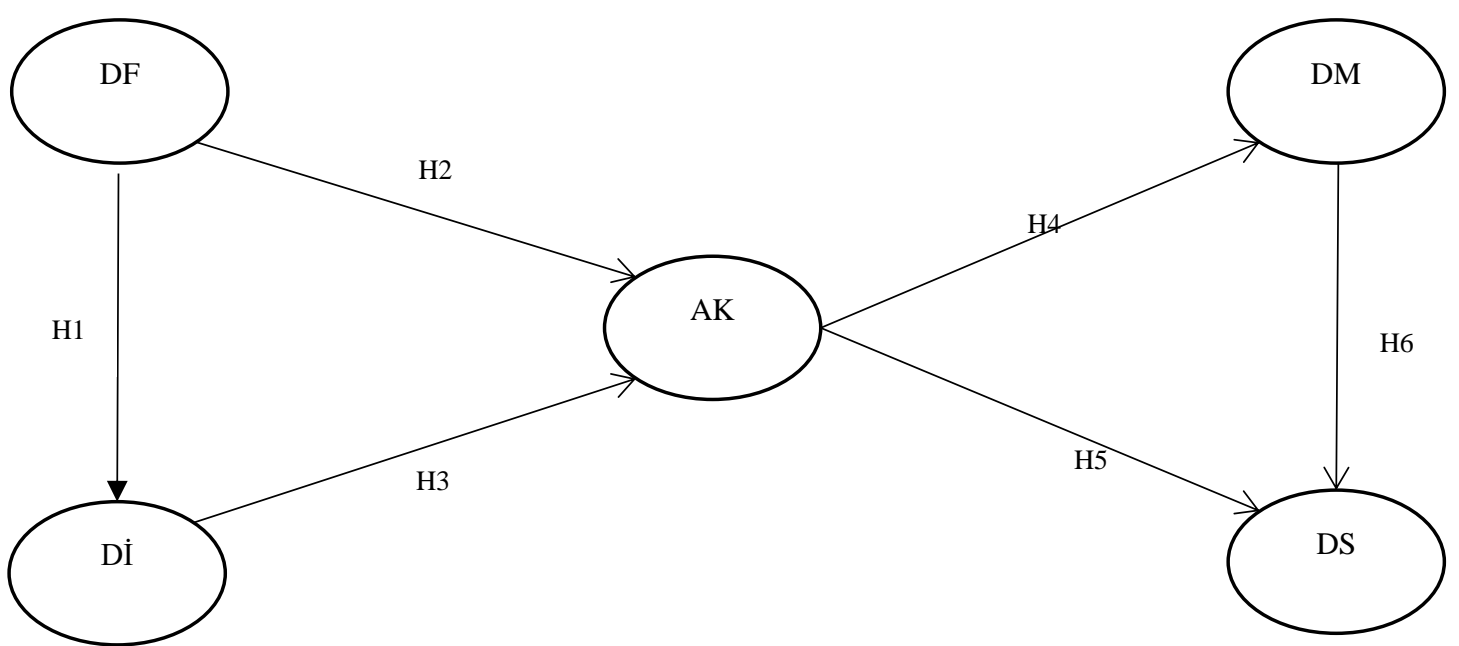

(DF:Destinasyon Farkındalığı; Di: Destinasyon İmajı; AK: Algılanan Kalite; DM: Destinasyon Memnuniyeti; DS: Destinasyon Sadakati)

\section{Araştırmanın Yöntemi}

Araştırmada önerilen modeli test etmek için sayısal verilere odaklanan nicel araştırma yöntemi kullanılmış olup, verilerin toplanmasında anket tekniğinden yararlanılmıştır.

\section{1. Ölçeklerin Hazırlanması}

Verilerin toplanmasında kullanılacak olan anket üç bölümden oluşmaktadır. İlk bölümde katılımcıların destinasyon marka değeri algısını ölçmeye yönelik dört boyut ve 19 maddeden oluşan destinasyon marka değeri ölçeği yer almaktadır. Bu ölçekte yer alan destinasyon farkındalık boyutuna ait maddeler Boo ve diğ. (2009); destinasyon imajına ait maddeler Martin ve diğ. (2018); destinasyondan algılanan kalite boyutuna ait maddeler Boo ve diğ. (2009) ile Yağmur ve Kolukısa (2016); destinasyon sadakati boyutuna ait maddeler Kocaman ve Güngör (2012) ile Yang ve diğ. (2015) çalışmalarında kullandıkları ölçeklerden yararlanılarak hazırlanmıştır. İkinci bölümde yer alan destinasyon memnuniyetinin ölçülmesinde Martin vd.'nin (2018) dört maddeden oluşan önermeleri kullanılmıştır. Üçüncü bölümde ise katılımcıların demografik özelliklerini belirleye yönelik sekiz soru belirlenmiştir. Birinci ve ikinci bölümde katılımcıların destinasyon marka değeri ve destinasyon memnuniyetini belirlemeye yönelik oluşturulan maddeler 5'li Likert tipi (1:Kesinlikle katılmıyorum, 2:Katılmıyorum, 3: Ne katılıyorum ne katılmıyorum, 4:Katılıyorum, 5:Kesinlikle katılıyorum) ölçekle ölçülmüştür. Katılımcıların kişisel özelliklerini belirlemeye yönelik oluşturulan soruların bazıları açık uçlu, bazıları ise kapalı uçlu sorulmuştur. Destinasyon marka değeri ve destinasyon memnuniyeti ölçeklerinde yer alan İngilizce maddeler, alanında uzman bir tercüman tarafından Türkçe'ye çevrilmiş ve anket formu Türkçe olarak oluşturulmuştur.

\section{2. Örnekleme Süreci, Veri Toplama ve Verilerin Analizi}

Araştırmanın evrenini, Isparta iline gelen ve en az 1 gece konaklama yapan yerli turistler oluşturmaktadır. Evrenin tümüne ulaşılmasının mümkün olmaması sebebiyle örnekleme yöntemi uygulanmış ve tesadüfi olmayan yöntemlerden kolayda örnekleme yöntemi tercih edilmiştir. Bu doğrultuda, Isparta ili merkezinde faaliyet göstermekte 
olan otel işletmeleri örneklem kapsamına alınmıştır. Isparta İ Kültür ve Turizm Müdürlüğünün web sayfasından elde edilen bilgilere göre, Isparta merkezde bakanlık belgeli 10 otel işletmesi faaliyet göstermektedir. Bu 10 otel işletmesinden beş tanesi, yapılan sözlü görüşmeler sonucunda araştırmaya katılmayı kabul etmişlerdir. Konaklayan müşterilerine doldurtmak üzere 200'er anket, toplamda ise 1000 anket araştırmaya katılmayı kabul eden otel işletmelerinin Önbüro departmanına bırakılmıştır. Her bir otelde, anket formlarını otelde konaklayan müşterilere doldurtulması ve anketlerin takibi için Önbüro müdürü tarafından bir resepsiyonist görevlendirilmiştir. Araştırmaya katılan beş otel işletmesinden toplam 489 anketin geri dönüşü olmuştur. Fakat 73 tanesi, katılımcıların eksik doldurduğunun belirlenmesi ve cevap verilmeyen (boş bırakılan) fazla soruların olması sebebiyle değerlendirmeye alınmamış, geri kalan 416 anket değerlendirmeye alınmıştır.

Ankette yer alan tüketici temelli destinasyon marka değeri ve destinasyon memnuniyeti ölçeklerinin yapı geçerliliğini sağlamak amacıyla AMOS 22.0 istatistiki paket programından yararlanılmıştır. SPSS 22.0 paket programı ile ölçeklerin güvenilirliği, tanımlayıcı istatistikler ve katılımcıların demografik dağılımları tespit edilmiştir. En son aşamada araştırmanın hipotezlerini test etmek amacı ile yapısal eşitlik modellemesi kurulmuş ve hipotezler yol analizi ile test edilmiştir.

\subsection{Araştırmada Kullanılan Ölçeklerin Testi}

Destinasyon memnuniyet ölçeği ve tüketici temelli destinasyon marka değeri ölçeğinin her bir boyutunun (destinasyon farkındalığı, destinasyon imajı, algılanan kalite ve destinasyon sadakati) yapı geçerliliğini ortaya koymak amacıyla, AMOS 22 istatistik paket programı ile birinci düzey tek faktörlü doğrulayıcı faktör analizi (DFA) gerçekleştirilmiştir. Gerçekleştirilen analiz sonucunda elde edilen değerler, kabul edilebilir uyum değerler arasında olmadığından programın önerdiği modifikasyonlar yapılmıştır. Bunun için destinasyon imajı boyutundan iki madde modelden çıkartılmış olup, diğer boyutlarda (destinasyon farkındalığı, algılanan kalite, destinasyon sadakati ve destinasyon memnuniyeti) bazı hata terimleri arasında korelasyon oluşturulmuştur. Gerçekleştirilen modifikasyonlar neticesinde, önerilen uyum değerleri elde edilmiştir (Tablo 1).

Tablo 1: Ölçeklerin Uyum Değerleri

\begin{tabular}{|c|c|c|c|c|c|c|}
\hline $\begin{array}{l}\text { Destinasyon } \\
\text { Farkındalığı }\end{array}$ & $\begin{array}{l}\mathbf{x}^{2} \\
1,368\end{array}$ & $\begin{array}{l}d f \\
1\end{array}$ & $\begin{array}{l}\mathbf{x}^{2} / \mathbf{d f} \\
1,368\end{array}$ & $\begin{array}{l}\text { GFI } \\
, 998\end{array}$ & $\begin{array}{l}\text { CFI } \\
1,000\end{array}$ & $\begin{array}{r}\text { RMSEA } \\
, 030\end{array}$ \\
\hline Destinasyon İmajı & 11,623 & 5 & 2,325 & ,989 & 991 & ,056 \\
\hline Algılanan Kalite & 2,768 & 1 & 2,768 & ,997 & ,998 & ,065 \\
\hline Destinasyon Sadakati & 2,612 & 1 & 2,612 & ,989 & 991 & ,066 \\
\hline $\begin{array}{l}\text { Destinasyon } \\
\text { Memnuniyeti }\end{array}$ & ,483 & 1 & ,483 & ,999 & 1,000 & ,000 \\
\hline İyi Uyum Değerleri* & & & $\leq 3$ & $\geq 0,90$ & $\geq 0,97$ & $\leq 0,05$ \\
\hline $\begin{array}{l}\text { Kabul Edilebilir Uyum } \\
\text { Değerleri* }\end{array}$ & & & $\leq 4-5$ & $\geq 0,89-0,85$ & $\geq 0,95$ & $\leq 0,06-0,08$ \\
\hline
\end{tabular}

*Kaynak: Meydan ve Şeşen, 2015:37

Tek faktörlü DFA sonucunda elde edilen destinasyon farkındalığı $\left(X^{2} / \mathrm{df}=1,36\right.$; RMSEA= ,03; CFI= 1,0; GFI= ,99), destinasyon imajı $\left(X^{2} / d f=2,32 ; \mathrm{RMSEA}=, 056 ; \mathrm{CFI}=\right.$ ,99; $\mathrm{GFI}=, 98)$, algılanan kalite $\left(\mathrm{X}^{2} / \mathrm{df}=2,76\right.$; $\left.\mathrm{RMSEA}=, 065 ; \mathrm{CFI}=, 99 ; \mathrm{GFI}=, 99\right)$, 
destinasyon sadakati $\left(\mathrm{X}^{2} / \mathrm{df}=2,61 ; \mathrm{RMSEA}=, 066 ; \mathrm{CFI}=1,0 ; \mathrm{GFI}=, 99\right)$ ve destinasyon memnuniyeti $\left(X^{2} / d f=, 48 ; \operatorname{RMSEA}=, 00 ; \mathrm{CFI}=1,0 ; \mathrm{GFI}=, 99\right)$ boyutlarına ait uyum iyiliği değerleri iyi uyum değerleri arasında yer aldığından tüm ölçeklerin yapı geçerliliği sağlanmıştır. Tüm bu ölçeklere ait maddelerin faktör yükleri ve güvenilirlik katsayıları Tablo 2'de verilmiştir.

Tablo 2: Ölçeklere Ait Faktör Yükleri ve Güvenilirlik Katsayıları

\begin{tabular}{|c|c|c|c|c|}
\hline $\begin{array}{l}\frac{\grave{d}}{\frac{L}{d}} \\
\frac{\mathrm{U}}{0}\end{array}$ & Maddeler & Kod & 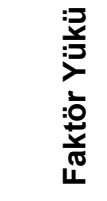 & 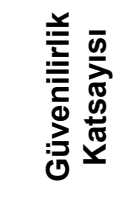 \\
\hline $\begin{array}{l}\text { Destinasyon } \\
\text { Farkındalığı } \\
\text { (D_F) }\end{array}$ & $\begin{array}{l}\text { Isparta ünlü bir destinasyondur. } \\
\text { Gül ve lavanta denildiğinde aklıma hemen Isparta gelir. } \\
\text { Isparta iyi bir isme ve şöhrete (üne) sahiptir } \\
\text { Isparta'nın özellikleri hemen aklıma gelir }\end{array}$ & $\begin{array}{l}\text { DF1 } \\
\text { DF2 } \\
\text { DF3 } \\
\text { DF4 }\end{array}$ & $\begin{array}{l}, 853 \\
, 797 \\
, 718 \\
, 820\end{array}$ & ,857 \\
\hline $\begin{array}{l}\text { Destinasyon } \\
\text { İmajı } \\
\text { (D_i ) }\end{array}$ & $\begin{array}{l}\text { Isparta tarihi ve doğal güzelliklere sahiptir } \\
\text { Isparta'nın eğlence ve gece hayatı çeşitli ve renklidir } \\
\text { Isparta keyifli bir destinasyondur } \\
\text { Isparta eğlenceli bir destinasyondur } \\
\text { Isparta inanılızaz bir destinasyondur }\end{array}$ & $\begin{array}{l}\text { Di1 } \\
\text { Di4 } \\
\text { Di5 } \\
\text { Di6 } \\
\text { Di7 }\end{array}$ & $\begin{array}{l}, 531 \\
, 550 \\
, 815 \\
, 824 \\
, 718\end{array}$ & ,812 \\
\hline $\begin{array}{l}\text { Algılanan } \\
\text { Kalite } \\
(\text { A_K) }\end{array}$ & $\begin{array}{l}\text { Isparta'da sunulan turistik ürünler mükemmeldir. } \\
\text { Isparta'da sunulan ürünler kalitelidir } \\
\text { Isparta'nın konaklama olanakları iyidir. } \\
\text { Isparta yüksek kalitede altyapıya sahiptir }\end{array}$ & $\begin{array}{l}\text { AK1 } \\
\text { AK2 } \\
\text { AK3 } \\
\text { AK4 }\end{array}$ & $\begin{array}{l}, 755 \\
, 885 \\
, 767 \\
, 628\end{array}$ & 854 \\
\hline $\begin{array}{l}\text { Destinasyon } \\
\text { Sadakati } \\
\text { (D_S) }\end{array}$ & $\begin{array}{l}\text { Ailemi ve arkadaşlarıma Isparta'yı tavsiye ederim } \\
\text { Fikrimi soranlara kesinlikle Isparta'yı önereceğim } \\
\text { Başka yerlerle kıyasladığımda ilk tercihim olur } \\
\text { Gelecekte Isparta'ya tekrar gelmek isterim }\end{array}$ & $\begin{array}{l}\text { DS1 } \\
\text { DS2 } \\
\text { DS3 } \\
\text { DS4 }\end{array}$ & $\begin{array}{l}, 839 \\
, 931 \\
, 745 \\
, 666 \\
\end{array}$ & ,883 \\
\hline $\begin{array}{l}\text { Destinasyon } \\
\text { Memnuniyeti } \\
\text { (D_M) }\end{array}$ & $\begin{array}{l}\text { Isparta'dan büyük keyif aldım } \\
\text { Isparta'yı tercih ettiğim için memnunum } \\
\text { Isparta'daki tatil deneyimimden memnun kaldım } \\
\text { Isparta'da sunulan hizmetler beklentilerimi karşıladı }\end{array}$ & $\begin{array}{l}\text { DM1 } \\
\text { DM2 } \\
\text { DM3 } \\
\text { DM4 }\end{array}$ & $\begin{array}{l}, 648 \\
, 829 \\
, 951 \\
, 827\end{array}$ & ,900 \\
\hline
\end{tabular}

Tablo 2 incelendiğinde tüm ölçeklere ait cronbach alfa katsayıları ,812 ile ,900 arasında değişmektedir. Ölçeklere ait bu katsayılar kabul edilebilir değerler arasında yer aldığından tüm ölçeklerin güvenilirliği de ortaya konulmuştur. Diğer taraftan her bir ölçeğe ait maddelerin faktör yüklerinin ,500 üzerinde olduğu görülmektedir.

\section{Bulgular}

Çalışmaya katılanların kişisel özelliklerini belirlemeye yönelik frekans analizi yapılmış ve sonuçları Tablo 3'te gösterilmiştir.

Tablo 3: Katılımcılara Ait Özellikler

\begin{tabular}{lll|lll}
\hline Cinsiyet & $\mathbf{n}$ & $\%$ & Medeni Durum & $\mathbf{n}$ & $\%$ \\
\hline Erkek & 205 & 49,3 & Evli & 266 & 63,9 \\
Kadın & 211 & 50,7 & Bekâr & 150 & 36,1 \\
Toplam & 416 & 100 & Toplam & 416 & 100 \\
\hline
\end{tabular}


Tablo 3'ün devamı

\begin{tabular}{|c|c|c|c|c|c|}
\hline Yaş & $\mathrm{n}$ & $\%$ & Isparta'ya Geliş Sayısı & $\mathrm{n}$ & $\%$ \\
\hline 29 yaş ve altı & 108 & 27,6 & $1 \mathrm{kez}$ & 136 & 34,6 \\
\hline 30-44 yaş arası & 189 & 48,2 & $2 \mathrm{kez}$ & 126 & 32,1 \\
\hline 45 yaş ve üzeri & 95 & 24,2 & 3 kez ve üzeri & 131 & 33,3 \\
\hline Toplam & 392 & 100 & Toplam & 393 & 100 \\
\hline Eğitim & $\mathbf{n}$ & $\%$ & Isparta'ya Geliş Amacı & $\bar{n}$ & $\%$ \\
\hline İlköğretim & 34 & 8,4 & İş amaçlı & 101 & 24,9 \\
\hline Lise & 131 & 32,3 & $\begin{array}{l}\text { Kırsal turizm (gül ve } \\
\text { lavanta) }\end{array}$ & 150 & 36,9 \\
\hline Lisans & 164 & 40,3 & Arkadaş/akraba ziyareti & 63 & 15,5 \\
\hline Lisansüstü & 77 & 19 & $\begin{array}{l}\text { Diğer (doğa, kültür, dini } \\
\text { vb.) }\end{array}$ & 92 & 22,7 \\
\hline Toplam & 406 & 100 & Toplam & 406 & 100 \\
\hline Meslek & $\mathbf{n}$ & $\%$ & Konaklama Süresi & $\mathbf{n}$ & $\%$ \\
\hline Doktor & 25 & 7,4 & 1 gece & 97 & 28,4 \\
\hline $\begin{array}{l}\text { Emekli } \\
\text { Ev hanımı }\end{array}$ & $\begin{array}{l}20 \\
40\end{array}$ & $\begin{array}{l}5,9 \\
11,9\end{array}$ & $\begin{array}{l}2 \text { gece } \\
3 \text { gece }\end{array}$ & $\begin{array}{l}95 \\
42\end{array}$ & $\begin{array}{l}27,9 \\
12,3\end{array}$ \\
\hline Kamu çalışanı & 80 & 23,8 & 4 gece & 29 & 8,5 \\
\hline Mühendis & 23 & 6,8 & 5 gece & 27 & 7,9 \\
\hline Öğrenci & 21 & 6,2 & 6 gece ve üzeri & 51 & 15 \\
\hline Özel Sektör Çalışanı & 128 & 38 & & & \\
\hline Toplam & 337 & 100 & Toplam & 341 & 100 \\
\hline
\end{tabular}

Tablo 3 incelendiğinde kadın katılımcıların az bir çoğunlukla (\% 50,7) erkeklere göre daha fazla olduğu görülmektedir. Katılımcıların \% 63,9'u bekâr, \% 48,2'sinin 30 44 yaş aralığındadır. \% 69,3'lük oranla lisans ve lisansüstü eğitim düzeyine sahip olan katılımcıların \% 32,3'ü de lise mezunudur. Bu verilere göre, genel olarak katılımcıların eğitim seviyelerinin yüksek olduğu söylenebilir. Meslek açısından bakıldığında \% 38'i özel sektör çalışanı, \% 23,8'i kamu çalışanıdır. \% 34,6'sı Isparta'ya ilk kez gelmiş olup, geri kalan \% 65,4'ü devamlı turist konumundadır. \% 28,4'ü bir gece, \% 27,9'u iki gece ve geri kalan \% 43,7'si üç gece ve üzeri konaklama yapmıştır. Isparta'ya geliş amaçlarına bakıldığında, \% 36,9'u kırsal turizm (gül ve lavanta) amaçlı, \% 24,9'u iş amaçlı, \% 15,5'i arkadaş/akraba ziyareti için Isparta'ya gelmişlerdir. Geri kalan \% 22,7 'si ise doğa turizmi, kültür turizmi ve dini turizm amaçlı Isparta'yı ziyaret etmişlerdir.

Tüketici temelli destinasyon marka değeri ve destinasyon memnuniyeti ölçeklerindeki maddelere ait tanımlayıcı istatistikler Tablo 4'te gösterilmiştir.

Tablo 4: Ölçek Maddelerine Ait Tanımlayıcı İstatistikler

\begin{tabular}{|c|c|c|c|c|c|}
\hline Kod & Maddeler & $\mathbf{n}$ & Ort. & S.S. & Varyans \\
\hline \multicolumn{3}{|c|}{ Destinasyon Farkındalığı } & 3,72 & 1,003 & 1,007 \\
\hline DF1 & Isparta ünlü bir destinasyondur. & 410 & 3,35 & 1,286 & 1,656 \\
\hline DF2 & $\begin{array}{l}\text { Gül ve lavanta denildiğinde aklıma hemen } \\
\text { Isparta gelir. }\end{array}$ & 415 & 3,94 & 1,299 & 1,687 \\
\hline DF3 & Isparta iyi bir isme ve şöhrete (üne) sahiptir & 411 & 3,62 & 1,132 & 1,283 \\
\hline DF4 & $\begin{array}{l}\text { Isparta denildiğinde, bazı özellikleri (kayak } \\
\text { merkezi, gül ve lavanta bahçeleri, gölleri vb.) } \\
\text { hemen aklıma gelir }\end{array}$ & 416 & 3,97 & 1,079 & 1,165 \\
\hline
\end{tabular}


Tablo 4'ün devamı

\begin{tabular}{|c|c|c|c|c|c|}
\hline \multicolumn{3}{|c|}{ Destinasyon İmajı } & \multirow{2}{*}{$\begin{array}{l}3,32 \\
3,64\end{array}$} & \multirow{2}{*}{$\begin{array}{l}, 843 \\
1,106\end{array}$} & \multirow{2}{*}{$\begin{array}{l}711 \\
1,224\end{array}$} \\
\hline Dì1 & $\begin{array}{l}\text { Isparta tarihi ve doğal güzelliklere sahip bir } \\
\text { destinasyondur }\end{array}$ & 414 & & & \\
\hline Dì2 & $\begin{array}{l}\text { Isparta turistik altyapıya (otel, restoran, } \\
\text { alışveriş vb.) sahiptir }\end{array}$ & 413 & 3,38 & 1,112 & 1,237 \\
\hline D3 & Isparta zengin bir yerel mutfağa sahiptir. & 414 & 3,08 & 1,224 & 1,498 \\
\hline Dí4 & $\begin{array}{l}\text { Isparta'nın eğlence ve gece hayatı çok çeşitli } \\
\text { ve renklidir }\end{array}$ & 408 & 3,00 & 1,295 & 1,678 \\
\hline Dì5 & Isparta keyifli bir destinasyondur & 407 & 3,50 & 1,077 & 1,162 \\
\hline Dí6 & Isparta eğlenceli bir destinasyondur & 406 & 3,39 & 1,121 & 1,257 \\
\hline Dí7 & $\begin{array}{l}\text { Isparta inanılmaz (hayran bırakan) bir } \\
\text { destinasyondur }\end{array}$ & 409 & 3,26 & 1,191 & 1,419 \\
\hline \multicolumn{2}{|c|}{ Algılanan Kalite } & & 3,29 & ,956 & ,914 \\
\hline AK1 & $\begin{array}{l}\text { Isparta'da sunulan turistik ürün ve hizmetler } \\
\text { mükemmeldir. }\end{array}$ & 411 & 3,25 & 1,159 & 1,346 \\
\hline AK2 & $\begin{array}{l}\text { Isparta'da sunulan ürün ve hizmetlerin } \\
\text { kalitesi benzer diğer şehirlere göre daha } \\
\text { yüksektir }\end{array}$ & 412 & 3,25 & 1,188 & 1,412 \\
\hline AK3 & $\begin{array}{l}\text { Isparta yüksek kalitede } \quad \text { konaklama } \\
\text { olanaklarına sahiptir. }\end{array}$ & 412 & 3,39 & 1,127 & 1,271 \\
\hline AK4 & Isparta yüksek kalitede altyapıya sahiptir & 408 & 3,29 & 1,137 & 1,293 \\
\hline \multicolumn{2}{|c|}{ Destinasyon Sadakati } & & 3,53 & 1,031 & 1,064 \\
\hline DS1 & $\begin{array}{l}\text { Ailemi ve arkadaşlarımı Isparta'ya gitmeleri } \\
\text { konusunda kesinlikle teşvik edeceğim }\end{array}$ & 411 & 3,58 & 1,191 & 1,419 \\
\hline DS2 & $\begin{array}{l}\text { Fikrimi soranlara kesinlikle Isparta'yı } \\
\text { önereceğim }\end{array}$ & 403 & 3,64 & 1,199 & 1,440 \\
\hline DS3 & $\begin{array}{l}\text { Isparta'yı diğer şehirlerle kıyasladığımda } \\
\text { tercihim Isparta olur }\end{array}$ & 414 & 3,36 & 1,239 & 1,536 \\
\hline DS4 & Gelecekte Isparta'ya tekrar gelmek isterim & 411 & 3,55 & 1,199 & 1,438 \\
\hline \multicolumn{2}{|c|}{ Destinasyon Memnuniyeti } & & 3,66 & 1,041 & 1,085 \\
\hline DM1 & $\begin{array}{l}\text { Isparta'da geçirdiğim zamandan büyük keyif } \\
\text { aldım }\end{array}$ & 411 & 3,62 & 1,193 & 1,424 \\
\hline DM2 & Isparta'yı tercih ettiğim için memnunum & 413 & 3,69 & 1,155 & 1,336 \\
\hline DM3 & Isparta'daki tatil deneyimimden memnun & 412 & 3,70 & 1,175 & 1,382 \\
\hline DM4 & $\begin{array}{l}\text { Isparta'da sunulan hizmetler beklentilerimi } \\
\text { karşıladı }\end{array}$ & 412 & 3,62 & 1,248 & 1,558 \\
\hline
\end{tabular}

Tablo 4'te ölçeklerin maddelerine ait ortalamalar, standart sapma ve varyans değerleri görülmektedir. Ortalama değerleri incelendiğinde en yüksek ortalama değerine sahip "Isparta denildiğinde, bazı özellikleri (kayak merkezi, gül ve lavanta bahçeleri, gölleri vb.) hemen aklıma gelir" ve "gül ve lavanta denildiğinde aklıma hemen Isparta gelir" maddeleridir. En az ortalama değerine sahip olan madde ise "Isparta'nın eğlence ve gece hayatı çok çeşitli ve renklidir" ifadesidir. Her bir ölçeğin ortalama değerine göre, en yüksek ortalama 3,72 ile destinasyon farkındalığın en önemli boyut olarak bulunması, Boo ve diğ. (2009)'nin çalışma sonuçları ile örtüşmektedir. En düşük ortalama değerine sahip boyutlar sırası ile algılanan kalite $(3,29)$ ile destinasyon imajı $(3,32)$ 'dir. Destinasyon farkındalığı boyutunun en önemli boyut olduğu bulgusu, Bu sonuçlara göre, Isparta ilinin turizm değeri olarak ön plana 
çıkan gül ve lavanta bahçeleri ile Davraz Kayak Merkezi'nin katılımcılarda farkındalık oluşturmasına rağmen, algılanan hizmet kalitesinin düşük olması da destinasyon imajını olumsuz yönde etkileyebileceği söylenebilir.

Çalışmanın son aşamasında araştırma modelini test etmek amacı ile yapısal eşitlik modelinden faydalanılmıştır. Model oluşturulmadan önce modelde yer alacak değişkenler arasındaki ilişkileri incelemek amacıyla korelasyon analizi yapılmış ve sonuçlar Tablo 5'te gösterilmiştir. Tabloda görüldüğü gibi tüm değişkenler arasında anlamlı ve pozitif yönde ilişkiler vardır. Dolayısıyla değişkenler arasındaki etkileşimler öngörülebilmektedir. Diğer taraftan oluşturulacak olan modelde değişkenler arasında çoklu doğrusal bağlantı olup olmadığına bakılmış olup, elde edilen tolerans ve VIF değerlerine (Tolerans > .23; VIF < 10) göre böyle bir sorunun olmadığı tespit edilmiştir.

Tablo 5: Değişkenlere Ait Korelasyon Matrisi

\begin{tabular}{|c|c|c|c|c|c|c|}
\hline Değişkenler & & 음 & 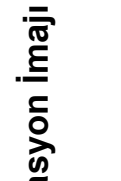 & 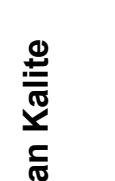 & $\sum_{0}^{\circ}=$ & 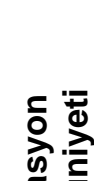 \\
\hline $\begin{array}{l}\text { Destinasyon } \\
\text { Farkındalığı }\end{array}$ & $\begin{array}{l}\text { Pearson } \\
\text { Cor. }\end{array}$ & & & & & \\
\hline Destinasyon İmajı & $\begin{array}{l}\text { Pearson } \\
\text { Cor. }\end{array}$ &, $544^{\star *}$ & 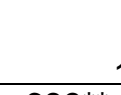 & & & \\
\hline Algılanan Kalite & $\begin{array}{l}\text { Pearson } \\
\text { Cor. }\end{array}$ & $495^{\star \star}$ &, $689^{* *}$ & 1 & & \\
\hline $\begin{array}{l}\text { Destinasyon } \\
\text { Sadakati }\end{array}$ & $\begin{array}{l}\text { Pearson } \\
\text { Cor. }\end{array}$ &, $580^{\star *}$ &, $690^{* *}$ &, $653^{\star *}$ & 1 & \\
\hline $\begin{array}{l}\text { Destinasyon } \\
\text { Memnuniveti }\end{array}$ & $\begin{array}{l}\text { Pearson } \\
\text { Cor. }\end{array}$ &, $593^{\star \star}$ &, $625^{\star \star}$ &, $633^{\star *}$ &, $805^{\star \star}$ & 1 \\
\hline
\end{tabular}

Araştırmanın hipotezlerini test etmek amacı ile Şekil 2'de gösterilen yapısal eşitlik modeli oluşturulmuştur. Modelin iyi uyum değerlerinin sağlanabilmesi için programın ürettiği değerler doğrultusunda bazı modifikasyonlar yapılmıştır. Bunun için destinasyon farkındalığı, destinasyon imajı, algılanan kalite ve destinasyon memnuniyeti ölçeklerinden birer madde olmak üzere toplamda dört madde modelden çıkartılmıştır. Bu işlemler sonucunda yapısal modelin iyi uyum değerleri sağlanmıştır (Tablo6). 
Şekil 2: Yapısal Eşitlik Modeli

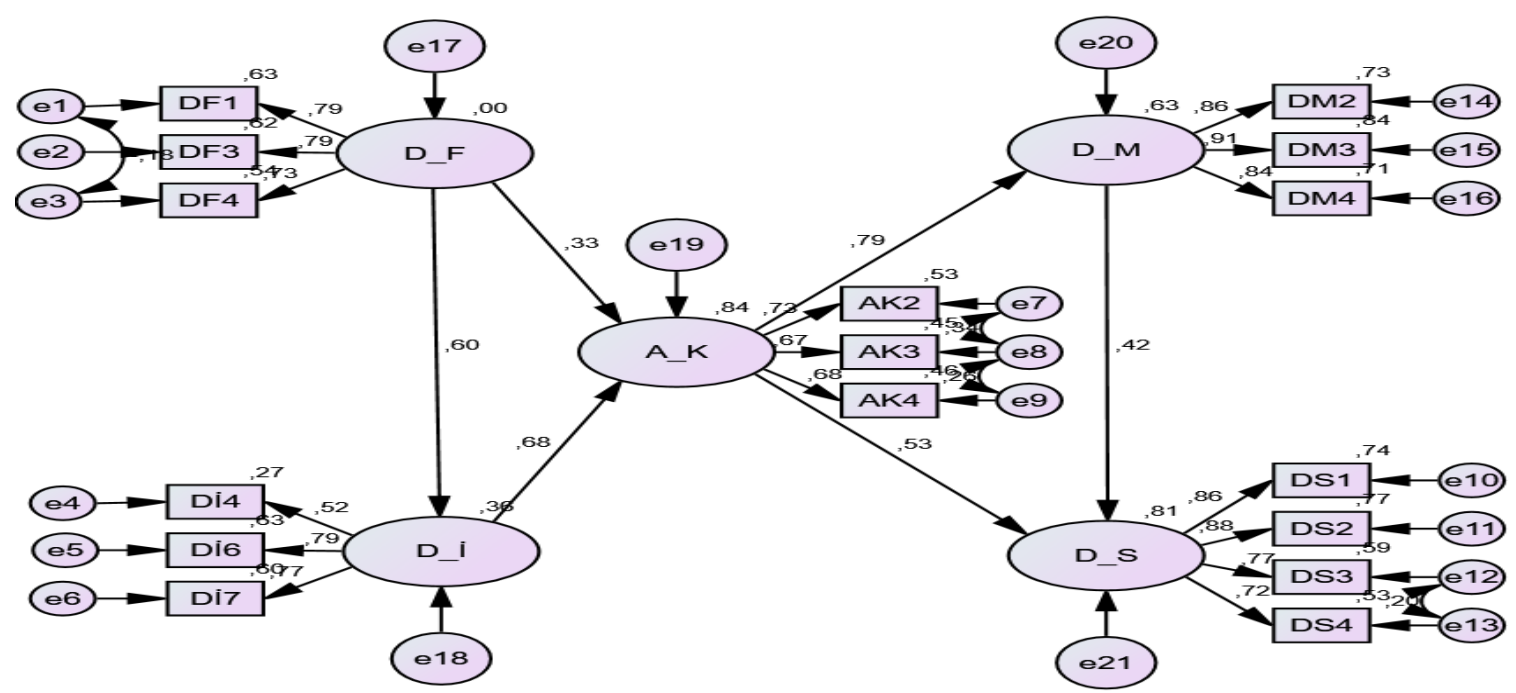

Tablo 6: Yapısal Eşitlik Modeli Uyum Değerleri

\begin{tabular}{|c|c|c|c|c|c|c|}
\hline \multirow{3}{*}{$\begin{array}{l}\text { Yapısal Eşitlik Modeli } \\
\text { İyi Uyum Değerleri* }\end{array}$} & $\overline{x^{2}}$ & df & $x^{2} / d f$ & GFI & CFI & RMSEA \\
\hline & 323,429 & 94 & 3,441 & ,917 & ,945 & ,077 \\
\hline & & & $\leq 3$ & $\geq 0,90$ & $\geq 0,97$ & $\leq 0,05$ \\
\hline $\begin{array}{l}\text { Kabul Edilebilir Uyum } \\
\text { Değerleri* }^{*}\end{array}$ & & & $\leq 4-5$ & $\geq 0,89-0,85$ & $\geq 0,95$ & $\begin{array}{ll}\leq & 0,06- \\
0,08 & \end{array}$ \\
\hline
\end{tabular}

*Kaynak: Meydan ve Şeşen (2015:37)

Amos 22.0 istatistik paket programı vasıtasıyla gerçekleştirilen yol analiz sonuçlarına göre araştırmanın hipotez test sonuçları Tablo 7'de gösterilmiştir.

Tablo 7: Araştırmanın Hipotez Test Sonuçları

\begin{tabular}{|c|c|c|c|c|c|c|c|}
\hline \multicolumn{2}{|r|}{ Hipotezler } & $\beta$ & S.H. & C.R. & p & $\mathbf{R}^{2}$ & Sonuç \\
\hline $\mathrm{H} 1$ & Destinasyon Farkındalığı $\longrightarrow$ Destinasyon İmajı & 60 & ,053 & 7,47 & *** & ,35 & Desteklendi \\
\hline $\mathrm{H} 2$ & Destinasyon Farkındalığı $\longrightarrow$ Algılanan Kalite & ,33 & ,052 & 5,45 & *** & \multirow{2}{*}{,83 } & Desteklendi \\
\hline $\mathrm{H} 3$ & $\longrightarrow \quad$ Algilanan Kalite & 68 & 112 & 7,78 & *** & & Desteklendi \\
\hline $\mathrm{H} 4$ & $\longrightarrow$ Destinasyon Memnuniyeti & ,79 & ,069 & 13,2 & *** & 63 & Desteklendi \\
\hline H5 & $\longrightarrow$ Destinasyon Sadakati & ,53 & ,089 & 7,02 & *** & \multirow{2}{*}{,80 } & Desteklendi \\
\hline $\mathrm{H} 6$ & Destinasyon Memnuniyeti $\longrightarrow$ Destinasyon Sadakati & ,42 & 071 & 6,11 & *** & & Desteklendi \\
\hline
\end{tabular}

Tablo 7'de elde edilen değerlere göre standardize edilmiş beta katsayısı anlamlı olan tüm hipotezler kabul edilmiştir. Modele ait elde edilen $\mathrm{R}^{2}$ değerlerine göre, destinasyon imajının \% 35'i destinasyon farkındalığıyla; algılanan kalitenin \% 83'ü destinasyon farkındalığı ve destinasyon imajıyla; destinasyon memnuniyetinin \% 63'ü algılanan kaliteyle ve destinasyon sadakatinin \% 80'i algılanan kalite ve destinasyon memnuniyetiyle açıklanmaktadır. 


\section{Sonuç ve Öneriler}

Araştırmada, TTDMD boyutları arasındaki etkileşimleri kapsayan ve destinasyon memnuniyetinin bu etkileşimler arasındaki rolünü ortaya koyacak olan model doğrulanmıştır. Turizm pazarlaması kapsamında TTDMD boyutlarına destinasyon memnuniyet değişkenini ilave eden az sayıdaki çalışmalardan biri olmasının yanı sıra, farklı bir destinasyon marka değer modeli ortaya koyarak, alanyazına katkıda bulunmaktadır. Model içinde yer alan boyutlar arasındaki ilişkilerin tümünün anlamlı çıkması, destinasyon marka değeri boyutları arasında bir etkileşimin olduğunun göstermekte ve Konecnik ve Gartner (2007), Gartner (2010), Kocaman ve Güngör (2012), Im ve diğ. (2012), Yağmur ve Kolukısa (2016) araştırma sonuçlarını desteklemektedir. Doğrulanan modele göre, ardışık bir şekilde destinasyon farkındalığı ile destinasyon imajını algılanan destinasyon kalitesini, algılanan destinasyon kalitesi de destinasyon memnuniyeti ile destinasyon sadakatini olumlu yönde etki etmektedir. Bununla birlikte, modelde yer alan yol analizlerinin standardize edilmiş beta katsayı ve $\mathrm{R}^{2}$ değerlerine göre; destinasyon imajının algılanan destinasyon kalitesini, algılanan destinasyon kalitesi de destinasyon memnuniyetini güçlü bir şekilde etkilemesinden dolayı, algılanan destinasyon kalitesinin destinasyon memnuniyetinin temel belirleyicisi olduğu söylenebilir. Başka bir ifadeyle sırasıyla; destinasyon farkındalığının artırılması destinasyon imajının, destinasyon imajının artırıması algılanan destinasyon kalitesinin, algılanan destinasyon kalitesinin artırıması da destinasyon memnuniyeti ve destinasyon sadakatinin yükselmesine neden olacaktır.

İkinci olarak destinasyon memnuniyetinin modelde önemli bir rol oynaması da diğer bir teorik çıktısıdır. Destinasyon memnuniyeti turizm alanında yoğun bir şekilde ele alınsa da sınırlı sayıda çalışma TTDMD modeline dâhil etmiştir. Araştırmada elde edilen bulgulara göre destinasyon memnuniyeti destinasyon sadakatini olumlu yönde etkilemektedir. Ayrıca memnuniyet ile sadakat arasındaki korelasyonun yüksek çıkması destinasyon memnuniyetinin, turistlerin destinasyonu tekrar ziyaret etme niyeti ve başkalarına tavsiye etme isteği açısından güçlü bir sadakat oluşturmada temel değişken olarak görünmektedir. Destinasyon imajının da algılanan destinasyon kalitesini güçlü bir şekilde etki etmesi sonucu, Konecnik ve Gartner (2007) ve Boo vd'nin. (2009) imajın TTDMD boyutları arasında en önemli boyut olduğu sonuçları ile örtüşmektedir. Ayrıca algılanan destinasyon kalitesinin destinasyon memnuniyetini etkilemesi Chen ve Tsai (2007) ile Martin ve diğ. (2018)'nin; destinasyon sadakatini etkilemesi ise Boo ve diğ. (2009) ile Yang ve diğ. (2015)'nin çalışmaları ile benzeşmektedir.

$\mathrm{Bu}$ çalışmadan elde edilen sonuçlar, destinasyon yöneticilerine destinasyon marka değeri oluşturulması sürecinde, doğru strateji ve politikaların uygulanmasında katkı sağlayabilir. Öncelikle marka farkındalığının, TTMD'nin ilk adımı olduğu göz önüne alındığında (Konecknik, 2006) destinasyon yöneticilerinin önceliği, destinasyonun bilinirliğini artırma faaliyetleri olmalıdır. Analiz sonuçları destinasyon farkındalığının algılanan destinasyon kalitesini ve destinasyon imajını olumlu yönde etkilediğini ortaya koyduğundan dolayı, yöneticilerin Isparta destinasyonuna yönelik geleneksel reklam ve tanıtım faaliyetlerini yaparak ve sosyal medyayı da etkin bir şekilde kullanarak destinasyonun farkındalığını artırmaları gerekmektedir. Turistlerin de destinasyon farkındalığına yönelik algılarının artması da Isparta destinasyon imajının artmasına neden olacaktır. Bir destinasyonun rekabet avantajı sağlamasında önemli bir araç olan imaj, destinasyonun ana kaynakları ve çekiciliklerine dayanmaktadır. Örneğin doğal güzellikleri, tabiat parkları, gül ve lavanta bahçeleri ile önemli çekiciliklere sahip olan Isparta destinasyonu kırsal turizm türüne odaklanarak, 
konumlandırma stratejileri çerçevesinde destinasyonun imajını yaratmaya veya güçlendirmeye odaklanmalıdır.

Algılanan destinasyon kalitesinin hem memnuniyet hem de sadakatin belirleyicisi olmasına rağmen, algılanan kalite düzeyinin orta düzeyde çıkmasından dolayı yöneticilerin hizmet kalitesini iyileştirmek için, belli periyotlarda hizmet kalitesi ölçümü memnuniyet - sadakat ölçümlerini ve değerlendirmelerini yapmaları gerekmektedir. Turist beklentilerinin karşılanması veya aşılması durumunda, algılanan destinasyon kalitesi yüksek çıkacak ve bu durum da turist memnuniyetini olumlu yönde etkileyecektir. Ayrıca olası turist şikâyetlerinin çözümü için şikayet hattı, şehir içinde danışma ofisleri ve sosyal iletişim merkezlerinin kurulması da turist memnuniyetsizliğini en aza indirgeyecektir. Son olarak memnun turistlere doğrudan pazarlama yöntemleri ve bazı teşviklerle gelecekte tekrar ziyaret etme olasılıkları artırılabilir. Diğer taraftan Yang ve diğ. (2015)'nin ağızdan ağza pazarlamanın marka değeri üzerinde olumlu etkileri olduğu sonucu doğrultusunda, memnun ve sadık müşterileri Tripadvisor, otelpuan.com gibi seyahatle ilgili sosyal paylaşım sitelerinde destinasyonla ilgili olumlu deneyimlerini paylaşmaya yönlendirmeleri, hem destinasyonun farkındalığının hem de turist sayısının artmasına katkıda bulanabilir.

Her araştırmanın olduğu gibi bu çalışmanın da bazı sınırlılıkları vardır. Çalışmanın sadece Isparta destinasyonunda yerli turistler üzerinde yapılması, sonuçların genellenebilirliğini sınırlamaktadır. Dolayısıyla önerilen modelin farklı bir destinasyonda (örneğin deniz-kum-güneş turizmine yönelik) farklı örneklem grupları (örneğin yabancı turist gibi) test edilmesi farklı sonuçlar ortaya koyabilir. Diğer taraftan bu araştırmada kullanılan ölçek, Isparta destinasyonun marka değerinin ölçmektedir. Gelecekte yapılacak çalışmalar destinasyon hizmet kalitesi, elektronik ağızdan ağza iletişim gibi değişkenlerin TTDMD üzerindeki etkileri de araştııılabilir.

\section{Kaynakça}

Aaker D.A. (1991). Managing Brand Equity. New York NY: The Free Press

Aaker, D.A. (1996), 'Mesuring Brand Equity Across Products and Markets' California Management Review, 38(3), ss. 102-121.

Aktepe, C. ve Baş, M. (2008), 'Marka Bilgisi Sürecinde Marka Farkındalığı ve Algılanan Kalite (Beklenti) İlişkisi ve GSM Sektörüne Yönelik Bir Analiz' Gazi Üniversitesi İktisadi ve Idari Bilimler Fakültesi Dergisi, 10(1), ss. 81-96.

Albayrak, T. ve Caber, M. (2013), 'The Symmetric and Asymmetric Influences of Destination Attributes on Overall Visitor Satisfaction' Current Issues in Tourism, 16(2), ss. 149-166.

Boo, S., Busser, J. ve Baloğlu, S. (2009), 'A Model of Customer-Based Brand Equity and Its Application to Multiple Destinations' Tourism Management, 30, ss. 219231.

Callarisa, L., Garcia, J.S., Cardiff, J. ve Roshchina, A. (2012), 'Harnessing Social Media Platforms to Measure Customer-Based Hotel Brand Equity' Tourism Management Perspectives, 4, ss. 73-79.

Chen, C.F. ve Tsai, A. C. (2007), 'How Destination Image and Evaluative Factors Affect Behavioral Intentions?' Tourism Management, 28(4), ss. 1115-1122.

Chen, C.F. ve Chen, F.S. (2010), 'Experience Quality, Perceived Value, Satisfaction and Behavioral Intentions for Heritage Tourists' Tourism Management, 31, ss. 29-35.

Chekalina, T., Fuchs, M. ve Lexhagen, M. (2016) 'Customer-Based Destination Brand Equity Modeling: The Role of Destination Resources Value For Money, and Value in Use' Journal of Travel Research, 57(1), ss. 31-51. 
Chi, C.G. ve Qu, H. (2008), 'Examinig The Structural Relationships of Destination Image, Tourist Satisfaction and Destination Loyalty: An Integrated Approach' Tourism Management, 29(4), ss. 624-636.

Choi, J.G., Tkachenko, T. ve Sil, S. (2011), 'On the Destination Image of Korea by Russian Tourists' Tourism Management, 32(1), 193-194.

Cretu, A.E. ve Brodie, R.J. (2007), 'The Influence of Brand Image and Company Reputation Where Manufactures Market to Small Firms: A Customer Value Perspective' Industrial Marketing Management, 36(2), ss. 230-240.

Çetin, İ. (2017), Otel İşletmelerinde Marka Değeri ve Değer Yaratma, Ankara: Detay Yayıncilık.

Çetinsöz, C.B. ve Artuğer, S. (2013), 'Antalya İli'nin Marka Değerinin Ölçülmesine Yönelik Bir Araştırma' Anatolia: Turizm Araştırmaları Dergisi, 24(2), ss. 200-210.

Çetinsöz, C.B. ve Karakeçili, G. (2018), 'Turistik Destinasyonlarda Tüketici Temelli Marka Değerinin Ölçülmesi: Anamur Üzerine Bir Araştırma' Gaziantep University Journal of Social Sciences, 17(1), ss. 147-159.

Fuchs, M., Chekalina, T. ve Lexhagen, M. (2012), 'Destination Brand Equity Modeling and Measurement: A Summer Tourism Case From Sweden' In R. H. Tsiotsou and R. E. Goldsmith (Editörler), Strategic Marketing in Tourism Services, Wagon Lane Bingley:Emerald Group Publishing Limited, ss. 95-115.

Gartner, W.C. ve Ruzzier, M.K. (2010), 'Tourism Destination Brand Equity Dimensions' Journal of Travel Research, 50(5), ss. 471-481.

Gomez, M., Lopez, C. ve Molina, A. (2015), 'A model of Tourism Destination Brand Equity: The Case of Wine Tourism Destinations in Spain' Tourism Management, 51, ss. 210-222.

Gonzalez, M.E.A., Comesana, L.R. ve Brea, J.A. (2007), 'Assessing Tourist Behavioral Intentions Through Perceived Service Quality and Customer Satisfaction' Journal of Business Research, 60(2), ss. 153-160.

Guervos, R.A.C., Jamilena, D.M.F., Pena, A.L.P. ve Olmo, J.C. (2018), 'Influence of Tourist Geographical Context on Customer Based-Destination Brand Equity: An Empirical Analysis' Journal of Travel Research, 17, ss.1-13.

Hankinson, G. (2005), 'Destination Brand Images: A Business Tourism Perspective' Journal of Services Marketing, 19(1), ss. 24-32.

Hernandez-Labota, L. Solis-Radilla, M.A. ve Sanchez-Garcia, J. (2006), 'Tourism Destination Image, Satisfaction and Loyalty: A Study in Ixtapa-ZihuatanejoMexico' Tourism Geographies, 8(4), ss. 343-358.

Hsu, C.H.C., Oh, H. ve Assaf, G. (2012), 'A Costomer-Based Brand Equity Model for Upscale Hotels' Journal of Travel Research, 51(1), ss. 81-93.

Im, H.H., Kim, S.S., Elliot, S. ve Han, H. (2012), 'Conceptualizing Destination Brand Equity Dimensions From A Consumer-Based Brand Equity Perspective' Journal of Travel \& Tourism Marketing, 29, ss. 385-403.

Isparta İ Kültür ve Turizm Müdürlüğü (2019), 'Konaklama İstatistikleri', www.isparta.ktb.gov.tr. (06.09.2019).

İşler, B.D. (2018), 'Isparta İli Turizm Potansiyeli ve SWOT Analizi' İçinde Ö. Davras (Editör), Isparta Turizm Potansiyelinin Değerlendirilmesi, ss. 128-136, Konya.

Kavacık, M., Zafer, S. ve İnal, M.E. (2012), 'Turizmde Destinasyon Markalaması: Alanya Örneği' Erciyes Üniversitesi İktisadi ve İdari Bilimler Fakültesi Dergisi, 39, ss. 169-192.

Keller, K.L. (1993), 'Conceptualizing, Measuring, and Managing Customer-Based Brand Equity' Journal of Marketing, 57(1), ss. 1-22.

Kim, H., Kim, W.G. ve Jeong, A.A. (2003), 'The Effect of Consumer Based Brand Equity on Firms' Financial Prformance' Journal of Consumer Marketing, 20(4), ss. 335-351. 
Kim, H. ve Kim, W.G. (2005), 'The Relation Between Brand Equity and Firms' Performance in Luxury Hotels and Chain Restaurants' Tourism Management, 26, ss. 549-560.

Kim, W.G., Jin-Sun, B. ve Kim, H.J. (2008), 'Multidimensional Customer-Based Brand Equity and Its Consequences in Midpriced Hotels' Journal of Hospitality\&Tourism Research, 32(2), ss. 235-254.

Kocaman, S. ve Güngör, İ. (2012), 'Destinasyonlarda Müşteri Temelli Marka Değerinin Ölçülmesi ve Marka Değeri Boyutlarının Genel Marka Değeri Üzerindeki Etkileri: Alanya Destinasyonu Örneği' Uluslararası Alanya İşletme Fakültesi Dergisi, 4 (3), ss. 143-161.

Koçoğlu, C.M. (2019), 'Destinasyona Yönelik Marka İmajı ve Marka Sadakati İlişkisinde Algılanan Destinasyon Kalitesinin Aracılık Rolü' Seyahat ve Otel İşletmeciliği Dergisi, 16(1), ss. 34-47.

Konecnik, M. (2006), 'Croatian-Based Brand Equity For Slovenia As A Tourism Destination' Economic and Business Review, 8(1), ss. 83-108.

Konecnik, M. ve Gartner, W.C. (2007), 'Customer-Based Brand Equity for a Destinastion' Annals of Tourism Research, 34(2), ss. 400-421.

Kotler, P., Bowen, J.T. ve Makens, J.C. (2005), Marketing for Hospitality and Tourism, (4. Baskı), New Jersey: Pearson Prentice Hall.

Martin, H.S., Herrero, A. ve Salmones, M.M.G. (2018), 'An Interagtive Model of Destination Brand Equity and Tourist Satisfaction' Current Issues in Tourism, 22(16), ss. 1-22.

Meydan, C.H. ve Şeşen, H. (2015), Yapısal Eşitlik Modellemesi AMOS Uygulamaları, 2. Baskı, Ankara: Detay Yayıncılık.

Liu, M.T., Wong, I.A., Tseng, T.H. ve Chang, A.W. (2017), 'Applying Consumer Based Brand Equity in Luxury Hotel Branding' Journal of Business Research, 81, ss. 12-202.

Nam, J., Ekinci, Y., ve Whyatt, G. (2011), 'Brand Equity, Brandt Loyalty and Consumer Satisfaction' Annals of Tourism Research, 38(3), ss. 1009-1030.

Pektaş, F. (2017), Seyahat Motivasyonunu Oluşturan İtici ve Çekici Faktörlerin Tüketici Temelli Destinasyon Değeri Üzerine Etkisi, Yayınlanmamış Doktora Tezi, Nevşehir Hacı Bektaş Üniversitesi Sosyal Bilimler Enstitüsü, Nevşehir.

Pike, S., Bianchi, C., Kerr, G. ve Patti, C. (2010), 'Cunsumer-Based Brand Equity For Australia as a Long-Haul Tourism Destination in an Emerging Market' International Marketing Review, 27(4), ss. 434-449.

Ruzzier, M.K. (2010), 'Extending the Tourism Destination Image Concept into Consumer-Based Brand Equity for a Tourism Destination' Economic Research, 23(3), ss. 24-42.

Seric, M., Saura, I.G. ve Molina, M.E.R. (2014), 'How Can Integrated Marketing Communications and Advanced Technology Influence the Creation of CustomerBased Brand Equity? Evidence From the Hospitality Industry' International Journal of Hospitality Management, 39, ss. 144-156.

Trthaber (2019), 'Isparta'da Lavanta Tarlalarına Yoğun İlgi', www.trthaber.com.tr (19.09.2019).

Yağmur, Y. ve Kolukısa, C. (2016), 'Fransız Turistlerin Destinasyon Marka Değeri Deneyimleri: Kemer Yöresi Uygulaması' Gümüşhane Üniversitesi Sosyal Bilimler Enstitüsü Elektronik Dergisi, 7(16), ss. 80-98.

Yang, Y., Liu, X. ve Li, J. (2015), 'How Customer Experience Affects the CustomerBased Brand Equity for Tourism Destinations' Journal of Travel \& Tourism Marketing, 32(1), ss. 97-113.

Yıldız, E. (2015), 'Ağızdan Ağza İletişimin Tüketici Temelli Marka Değeri Boyutlarına Etkileri: Marka İmajının Aracılık Rolü' Business and Economics Research Journal, 6(3), ss. 163-181. 
Yüce, A. (2010), Bütünleyici Bir Model İle Marka Değeri Ölçümü, Yayınlanmamış Yüksek Lisans Tezi, Atatürk Üniversitesi Sosyal Bilimler Enstitüsü, Erzurum.

Wong, P.P.W. (2015), 'Role of Compenents of Destination Competitiveness in the Relationship Between Customer Based Brand Equity and Destination Loyalty' Current Issues in Tourism, 21(5), ss. 504-528.

Wong, P.P.W. ve Teoh, K. (2015), 'The Influence of Destination on Competitiveness on Customer-Based Brand Equity' Journal of Destination Marketing \& Management, 4(4), ss. 206-212.

Zabkar, V., Brencic, M.M. ve Dmitrovic, T. (2010), 'Modelling Perceived Quality, Visitor Satisfaction and Behavioural Intentions at the Destination Level' Tourism Management, 31(4), ss. 537-546. 